\title{
CLINICAL TRIAL OF INTRAVENOUS AND INTRAMUSCULAR IRON IN RHEUMATOID ARTHRITIS
}

BY

\author{
J. B. MILLARD AND H. STUART BARBER \\ From the Royal Devonshire Hospital, Buxton
}

(RECEIVED FOR PUBLICATION JUNE 8, 1955)

The common association of an anaemia with rheumatoid disease has been recognized for many years. It was commented upon by Glover (1928) and statistical confirmation was furnished by the Empire Rheumatism Council (1950). At one time thought to be the result of toxic absorption from the same infective focus producing the arthritis, the cause of the anaemia remains as obscure as that of the disease. As Sinclair and Duthie (1950) point out, a toxic depression of the bone marrow is not likely to be corrected by iron. It was suggested by Robinson (1943) that haemodilution occurred in the disease, but his methods of measuring blood volume have since been shown to be erroneous (Jeffrey, 1953). The anaemia is almost always hypochromic and recent studies indicate two possible aetiological factors, defective absorption of iron from the gut and a greatly increased demand for iron by some tissue or tissues as yet unidentified.

Whatever the cause, it is generally agreed that the restoration of the haemoglobin level to values as near normal as possible is an essential part of the treatment of rheumatoid disease. The prolonged administration of iron by mouth has not proved very effective (Ross, 1950). Blood transfusions have been given with good results, but the improvement has been transient (Simpson, Kersley, and Brooks, 1949). Iron given by the intravenous route has been shown to produce a more prolonged rise in the haemoglobin level (Sinclair and Duthie, 1950), but the difficulty of giving such injections to patients with joint deformities is a drawback as well as the liability to cause unpleasant side-reactions (Nissim, 1954). Furthermore, parenteral iron therapy in this form is not practicable in busy general practice. Clearly, an iron preparation for intramuscular injection free from side-effects and fairly rapidly absorbed would be a great advantage. This paper describes a clinical experiment to assess the relative value of oral iron against intravenous iron and of intravenous iron against intramuscular iron in the treatment of the anaemia of rheumatoid disease.

The oral iron used was ferrous gluconate in tablets of $300 \mathrm{mg}$. The intravenous preparation of iron (Ferrivenin) contains $20 \mathrm{mg}$. Fe per $\mathrm{ml}$. and the intramuscular preparation (Imferon)* contains $50 \mathrm{mg}$. Fe per $\mathrm{ml}$.

One hundred patients (92 females and 8 males) suffering from rheumatoid disease admitted to the wards of the Devonshire Royal Hospital were selected according to their haemoglobin level after an initial period of 2 weeks in hospital. It was found advisable to wait for this period, since some patients show a spontaneous rise in the haemoglobin level after a short period of hospital treatment, attributable perhaps to rest and change of diet. Estimations were carried out on admission and approximately 2 weeks later, and then at intervals of 4 weeks. Iron therapy was started during the third week in hospital.

A photo-electric absorptiometer was used to ascertain the haemoglobin percentage, taking 100 per cent. as equivalent to $14.8 \mathrm{~g}$. haemoglobin per $100 \mathrm{ml}$. The erythrocyte sedimentation rate was recorded at the same time as the haemoglobin by the Westergren technique.

\section{Method}

The experiment was divided into two series. Series 1, consisting of fifty patients who had a haemoglobin level of 70 per cent. $(10 \cdot 4 \mathrm{~g}$.) or less after 2 weeks in hospital, was divided into two groups of 25 each, the subjects being placed alternately into Group A or Group B. Group A were given oral ferrous gluconate in tablets of $300 \mathrm{mg}$. thrice daily for 30 days. Group B were given intravenous iron to a total of $1,500 \mathrm{mg}$. over a period of 8 days.

Series 2, comprising fifty patients who had a haemoglobin level of 80 per cent. $(11.9$ g.) or less, was also

\footnotetext{
* Manufactured by Bengers Ltd.
} 
divided into two groups of 25 . Group $\mathrm{C}$ was treated with intravenous iron to a total quantity of $1,500 \mathrm{mg}$. in 8 days. Group $\mathbf{D}$ was given intramuscular iron, the total dosage being calculated by multiplying the haemoglobin deficit by 25 and adding $250 \mathrm{mg}$. as recommended by the manufacturers.

\section{Haemoglobin}

\section{Results}

Series 1, Group A (Table I).--The oral iron group has a small average haemoglobin increase of 6.4 per cent. which remained virtually unaltered throughout the observation period. Six patients show a rise of 10 per cent. or more at 6 weeks and seven had a similar rise at 10 weeks. The results at 2 and 6 weeks show statistically significant difference.

Group B (Table I).-Four subjects had to be withdrawn from this group as they could not be followed up, but the remainder show an increase in the average haemoglobin level of 18.4 per cent. at 6 weeks and 24.6 per cent. at 10 weeks. All patients in this group responded, nineteen having a rise of 10 per cent. or over at 6 weeks and all maintaining the increase at 10 weeks. The results at 14 weeks are too few to analyse. The results at 2 and 6 weeks show a statistically significant difference.

Series 2, Group $C$ (Table I).-Three subjects could not be followed up and had to be withdrawn. Among the remainder a rise of 10 per cent. or more in the haemoglobin occurred in ten cases at 6 weeks and in twelve cases at 10 weeks. Three patients showed no response. The average haemoglobin increase was 8.8 per cent. at 6 weeks and 14.4 per cent. at 10 weeks. The results at 2 and 6 weeks show a statistically significant difference.

Group D (Table I).-Nine patients show a rise in haemoglobin of 10 per cent. or more at 6 weeks and nine had a similar rise at 10 weeks. Seven patients failed to give any response. The average increase was $8 \cdot 2$ per cent. haemoglobin at 6 weeks and 8.9 per cent. at 10 weeks. The figures at 14 weeks are insufficient to analyse. The results at 2 and 6 weeks show a statistically significant difference.

Erythrocyte Sedimentation Rate (Table II, opposite). - The results are given in a simplified form showing the distribution curve, average erythrocyte sedimentation rate, and range for each group.

Series 1, Group A.-There is very little change in the average erythrocyte sedimentation rate. Three subjects had a rise of over 30 per cent. and four subjects a fall of over 30 per cent. at the 6 th week, as compared with the 2nd week. The distribution curve shows a slight improvement at the 10th week, but five of the subjects with a high erythrocyte sedimentation rate previously (over $80 \mathrm{~mm}$.) were not available at this estimation period. The overall picture is a slight improvement. There is no statistical difference at 2 and 6 weeks.

Group B.-The average erythrocyte sedimentation rate fell by 16.5 per cent. at the 6 th week and a further 9 per cent. at the 10 th week. Six subjects had an improvement of over 30 per cent. No subjects deteriorated. The distribution curves show a gradual improvement. Of the four subjects not

TABLE I

HAEMOGLOBIN PERCENTAGES

\begin{tabular}{|c|c|c|c|c|c|c|c|c|}
\hline Series & Group & Time since Admission & & 0 & 2 & 6 & 10 & 14 \\
\hline \multirow{4}{*}{1} & \multirow{2}{*}{$\underset{\text { Oral }}{\text { A }}$} & $\underset{\text { Mean } \ldots}{\text { Range . . }} \quad \ldots$ & $\begin{array}{l}\dot{\cdot} \\
\cdot \\
\cdot\end{array}$ & $\begin{array}{c}71 \cdot 0 \\
53-81 \\
-\end{array}$ & $\begin{array}{c}64 \cdot 8 \\
56-70 \\
\pm 4 \cdot 04\end{array}$ & $\begin{array}{c}71 \cdot 2 \\
57-84 \\
\pm 6 \cdot 42\end{array}$ & $\begin{array}{c}73 \cdot 4 \\
62-90 \\
-\end{array}$ & $\begin{array}{l}72 \cdot 2 \\
-\end{array}$ \\
\hline & & No. of Observations & $\cdots$ & 13 & 25 & 25 & 20 & 10 \\
\hline & \multirow{2}{*}{$\begin{array}{c}\text { B } \\
\text { Intravenous }\end{array}$} & $\underset{\text { Mean ... }}{\text { Range . . }} \quad \ldots$ & \begin{tabular}{l|}
$\cdots$ \\
$\cdots$ \\
$\cdots$
\end{tabular} & $\begin{array}{c}68 \cdot 6 \\
59-83 \\
-\end{array}$ & $\begin{array}{r}64 \cdot 0 \\
50-70 \\
\pm 4 \cdot 87\end{array}$ & $\begin{array}{r}82 \cdot 4 \\
72-96 \\
\pm 5 \cdot 76\end{array}$ & $\begin{array}{c}88 \cdot 6 \\
72-104 \\
-\end{array}$ & $\begin{array}{c}83 \cdot 5 \\
-\end{array}$ \\
\hline & & No. of Observations & $\cdots$ & 13 & 21 & 21 & 17 & 12 \\
\hline \multirow{4}{*}{2} & \multirow{2}{*}{$\underset{\text { Intravenous }}{\mathrm{C}}$} & $\begin{array}{c}\text { Mean ... } \\
\text { Range . . . } \\
\text { Standard Deviation }\end{array}$ & $\begin{array}{l}\cdots \\
\cdots \\
\cdots\end{array}$ & $\begin{array}{c}71 \cdot 0 \\
54-80 \\
-\end{array}$ & $\begin{array}{r}71 \cdot 7 \\
60-77 \\
\pm 4 \cdot 68\end{array}$ & $\begin{array}{c}80 \cdot 5 \\
65-90 \\
\pm 6 \cdot 15\end{array}$ & $\begin{array}{c}86 \cdot 1 \\
62-102 \\
-\end{array}$ & $\begin{array}{c}87 \cdot 6 \\
-\end{array}$ \\
\hline & & No. of Observations & . & 22 & 22 & 22 & 19 & 10 \\
\hline & \multirow{2}{*}{$\underset{\text { Intramuscular }}{\text { D }}$} & $\begin{array}{c}\text { Mean } . . \\
\text { Range . . } \\
\text { Standard Deviation }\end{array}$ & $\begin{array}{l}\cdots \\
\cdots \\
\cdots\end{array}$ & $\begin{array}{c}73 \cdot 3 \\
55-87 \\
-\end{array}$ & $\begin{array}{r}71 \cdot 8 \\
51-80 \\
\pm 7 \cdot 80\end{array}$ & $\begin{array}{r}80 \cdot 0 \\
64-93 \\
\pm 6 \cdot 48\end{array}$ & $\begin{array}{c}80 \cdot 7 \\
73-98 \\
-\end{array}$ & $\begin{array}{c}84 \cdot 0 \\
-\end{array}$ \\
\hline & & No. of Observations & $\cdots$ & 24 & 25 & 25 & 22 & 11 \\
\hline
\end{tabular}


TABLE II

ERYTHROCYTE SEDIMENTATION RATES

(mm./hr Westergren)

\begin{tabular}{|c|c|c|c|c|c|c|c|}
\hline \multirow{2}{*}{ Group } & \multirow{2}{*}{ Series } & \multirow{2}{*}{$\begin{array}{l}\text { E.S.R. } \\
(\mathrm{mm} . / \mathrm{hr} .)\end{array}$} & \multicolumn{5}{|c|}{ Time since Admission (wks) } \\
\hline & & & 0 & 2 & 6 & 10 & 14 \\
\hline \multirow{6}{*}{ (1) } & \multirow[t]{3}{*}{$\underset{\text { Oral }}{\mathbf{A}}$} & $\begin{array}{c}0-19 \\
20-39 \\
40-59 \\
60-79 \\
80-99 \\
100 \text { and } \\
\text { over }\end{array}$ & $\begin{array}{l}1 \\
1 \\
2 \\
1 \\
7 \\
1\end{array}$ & $\begin{array}{l}0 \\
4 \\
4 \\
5 \\
9 \\
3\end{array}$ & $\begin{array}{l}1 \\
1 \\
8 \\
3 \\
8 \\
4\end{array}$ & $\begin{array}{l}1 \\
2 \\
7 \\
4 \\
3 \\
3\end{array}$ & $\begin{array}{l}0 \\
2 \\
2 \\
2 \\
2 \\
2\end{array}$ \\
\hline & & Total & 13 & 25 & 25 & 20 & 10 \\
\hline & & Average & 71 & 71 & 70 & 65 & 69 \\
\hline & \multirow[t]{3}{*}{$\begin{array}{c}\text { B } \\
\text { Intra- } \\
\text { venous }\end{array}$} & $\begin{array}{r}0-19 \\
20-39 \\
40-59 \\
60-79 \\
80-99 \\
100 \text { and } \\
\text { over }\end{array}$ & $\begin{array}{l}0 \\
3 \\
5 \\
0 \\
2 \\
3\end{array}$ & $\begin{array}{l}0 \\
5 \\
5 \\
4 \\
2 \\
5\end{array}$ & $\begin{array}{l}1 \\
6 \\
6 \\
3 \\
2 \\
3\end{array}$ & $\begin{array}{l}1 \\
4 \\
7 \\
3 \\
1 \\
1\end{array}$ & $\begin{array}{l}0 \\
2 \\
6 \\
1 \\
2 \\
0\end{array}$ \\
\hline & & Total & 13 & 21 & 21 & 17 & 11 \\
\hline & & Average & 62 & 66 & 55 & 49 & 53 \\
\hline \multirow{6}{*}{ (2) } & \multirow[t]{3}{*}{ 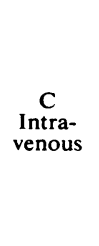 } & $\begin{array}{r}0-19 \\
20-39 \\
40-59 \\
60-79 \\
80-99 \\
100 \text { and } \\
\text { over }\end{array}$ & $\begin{array}{l}0 \\
4 \\
8 \\
6 \\
5\end{array}$ & $\begin{array}{l}0 \\
6 \\
7 \\
6 \\
5\end{array}$ & $\begin{array}{r}2 \\
7 \\
3 \\
10 \\
2 \\
1\end{array}$ & $\begin{array}{l}3 \\
5 \\
6 \\
4 \\
3 \\
1\end{array}$ & $\begin{array}{l}0 \\
2 \\
8 \\
1 \\
1\end{array}$ \\
\hline & & Total & 24 & 25 & 25 & 22 & 12 \\
\hline & & Average & 60 & 62 & 51 & 49 & 49 \\
\hline & \multirow[t]{3}{*}{$\underset{\substack{\text { Intra- } \\
\text { muscular }}}{\text { D }}$} & $\begin{array}{r}0-19 \\
20-39 \\
40-59 \\
60-79 \\
80-99 \\
100 \text { and } \\
\text { over }\end{array}$ & $\begin{array}{l}0 \\
3 \\
6 \\
1 \\
7\end{array}$ & $\begin{array}{l}0 \\
5 \\
3 \\
6 \\
4\end{array}$ & $\begin{array}{l}1 \\
7 \\
6 \\
1 \\
5 \\
2\end{array}$ & $\begin{array}{l}0 \\
5 \\
4 \\
3 \\
2 \\
4\end{array}$ & $\begin{array}{l}0 \\
2 \\
2 \\
2 \\
2 \\
2\end{array}$ \\
\hline & & Total & 22 & 22 & 22 & 18 & 10 \\
\hline & & Average & 72 & 66 & 55 & 63 & 70 \\
\hline
\end{tabular}

seen at the 10th week, two had a high erythrocyte sedimentation rate $(80-90 \mathrm{~mm}$.) and two had a low erythrocyte sedimentation rate $(20-39 \mathrm{~mm}$.) previously. The overall picture is one of improvement. The results at 2 and 6 weeks are significantly different.

Series 2, Group C.-At the 6th week the average erythrocyte sedimentation rate fell by $17 \cdot 5$ per cent., but returned to its previous level at the 10th week. Four subjects had left the group at the 10th week; of these, three had an erythrocyte sedimentation rate of under 40 , and the other was 40 at the 6th week. The distribution curve, when adjusted, shows an improvement. Eight subjects had an improvement of over 30 per cent. and one deteriorated by 30 per cent. at the 6 th week. The overall picture is one of slight improvement. The result at 2 and 6 weeks show a statistically significant difference.
Group D.-The average erythrocyte sedimentation rate fell by 17 per cent. at the 6th week and remained unchanged. The distribution curves show an improvement. The three subjects not estimated at the 10th week had an erythrocyte sedimentation rate of 40,60 , and 65 at the previous estimation. Five subjects had a 30 per cent. improvement and two a 30 per cent. deterioration at 6 weeks.

The overall picture is one of improvement. The results at 2 and 6 weeks are significantly different statistically.

\section{Discussion}

The results show that oral iron has little effect on the anaemia of rheumatoid disease, thus confirming the work of others. Intravenous iron evokes a good response with an increase in the haemoglobin and some improvement in the sedimentation rate. In the second series, starting with a higher initial haemoglobin, both groups show an increase, but at the 10th week the patients on intravenous iron were somewhat better. Nevertheless, if cases with an initial haemoglobin of 70 per cent. $(10.4 \mathrm{~g}$.) or under are compared, the average increase in Groups $\mathrm{C}$ and $\mathrm{D}$ is about 14 per cent., which is much the same as Group B, the intravenous group of the first series. Seven patients failed to respond to intramuscular iron compared with three in the intravenous iron groups. It must be concluded that intramuscular iron in the dosage given is more likely to produce a response than oral iron, but is less likely to be effective than intravenous iron. The total quantity of intramuscular iron was rather less than that given intravenously and this may account for the variation in effect. As there were no significant reactions with the intramuscular preparation there seems no contra-indication to augmenting the total amount by giving it over a long period.

Group A may be taken as a rough control group for comparison with intravenous and intramuscular iron medication, since so little alteration occurred in the haemoglobin levels.

Other workers (Sinclair and Duthie, 1949, 1950; Jeffrey, 1953; Ross, 1950) have suggested that a fall in the erythrocyte sedimentation rate occurs when the response is good to parenteral iron. Of the 29 patients who showed a rise of 10 per cent. or more in the haemoglobin level after intravenous iron, and of the nine who showed a similar response to intramuscular iron, sixteen had a high erythrocyte sedimentation rate (over $60 \mathrm{~mm}$.) and 22 had a moderately raised erythrocyte sedimentation rate. Thirteen of these cases showed an improvement of over 30 per cent. in the erythrocyte sedimentation rate, 24 remained unaltered, and one deteriorated by over 
30 per cent. (Of the thirteen cases, the initial erythrocyte sedimentation rate was high in six and moderately raised in seven.) This does not indicate any clear relationship between the haemoglobin and the sedimentation rate, nor was it found that the best results with parenteral iron occurred in patients with a low initial erythrocyte sedimentation rate.

\section{Conclusion}

The results of the observations in this series show that oral iron is of little value in the treatment of the anaemia of rheumatoid arthritis and that intramuscular iron and intravenous iron are both effective and give similar benefit.

It is suggested that intramuscular iron should be tried in larger doses.

\section{Summary}

(1) One hundred cases of rheumatoid arthritis with anaemia were treated by one of three methods:

(a) 25 subjects were given $300 \mathrm{mg}$. ferrous gluconate orally for one month;

(b) Fifty subjects were given intravenous iron (1,500 mg.);

(c) 25 subjects were given intramuscular iron (1,000 mg.).

(2) The resulting haemoglobin and erythrocyte sedimentation rate changes were analysed.

(3) It is concluded that oral iron has little value in the treatment of the anaemia of rheumatoid arthritis, and that intramuscular iron is as beneficial as intravenous iron and easier to administer.

We should like to acknowledge the help of Dr. L. Delicati (Resident Medical Officer), and thank the Medical Director, Research Department, Bengers Ltd., for supplies of Imferon.

\section{REFERENCES}

Empire Rheumatism Council (1950). Report of Scientific Advisory Committee, Annals of the Rheumatic Diseases, 9, Suppl.

Glover, J. A (1928) Ministry of Health Reports on Public Health and Medical Subjects, No. 52. H.M.S.O., London.

Jeffrey, M. R. (1953). Blood, 8, 502.

Nissim, J. A. (1954). Brit. med. J., 1, 352.

Robinson, G. L. (1943). Annals of the Rheumatic Diseases, 3, 207.

Ross, D. N. (1950). Ibid., 9, 358.

Simpson, N. R. W., Kersley, G. D., and Brooks, D. Hall (1949). Ibid., 8, 277.

Sinclair, R. J.' G., and Duthie, J. J. R. (1949). Lancet, 2, 646.

, (1950). Brit. med. J., 2, 1257.

Essai clinique du fer intraveineux et intramusculaire dans l'arthrite rhumatismale

RÉSUMÉ

(1) Cent cas d'arthrite rhumatismale avec de l'anémie furent traités par une des trois méthodes suivantes:

(a) 25 sujets reçurent $30 \mathrm{cgr}$. de glucolsate de fer trois fois par jour pendant un mois par voie buccale.

(b) 50 sujets reçurent du fer intraveineux $(1 \mathrm{~g} .50)$.

(c) 25 sujets reçurent du fer intramusculaire $(1 \mathrm{~g}$.).

(2) On analysa les chiffres consécutifs de l'hémoglobine et de la sédimentation globulaire.

(3) On conclut que le fer par voie buccale a peu de valeur dans le traitement de l'anémie de l'arthrite rhumatismale, et que le fer intramusculaire ne cède en rien au fer intraveineux, tout en étant plus facile à administrer.

Ensayo clínico del hierro endovenoso e intramuscular en la artritis reumatoide

\section{SUMARIO}

(1) Cien casos de artritis reumatoide con anemia fueron tratados con uno de los tres métodos siguientes:

(a) 25 sujetos recibieron $30 \mathrm{cgr}$. de gluconato de hierro tres veces al día durante un mes por vía oral.

(b) 50 sujetos recibieron hierro endovenoso $(1 \cdot 5 \mathrm{~g}$.).

(c) 25 sujetos recibieron hierro intramuscular $(1$ g.).

(2) Se analizaron las variaciones resultantes de las cifras de hemoglobina y de sedimentación eritrocitaria.

(3) Se concluye que el hierro oral tiene poco valor en el tratamiento de la anemia de la artritis reumatoide, y que el intramuscular es tan beneficioso como el endovenoso, además dè su administración más fácil. 